\title{
Chemical synthesis and binding activity of the trypanosomatid cap-4 structure
}

\author{
MAGDALENA LEWDOROWICZ, ${ }^{1}$ YAEL YOFFE, ${ }^{2}$ JOANNA ZUBEREK, ${ }^{1}{ }^{3 A C E K ~ J E M I E L I T Y, ~}{ }^{1}{ }^{3 A N U S Z ~ S T E P I N S K I, ~}{ }^{1}$ \\ RYSZARD KIERZEK, ${ }^{3}$ RYSZARD STOLARSKI, ${ }^{1}$ MICHAL SHAPIRA, ${ }^{2}$ and EDWARD DARZYNKIEWICZ ${ }^{1}$ \\ ${ }^{1}$ Department of Biophysics, Institute of Experimental Physics, Warsaw University, 02-089, Warsaw, Poland \\ ${ }^{2}$ Department of Life Sciences, Ben Gurion University of the Negev, Beer Sheva 84105, Israel \\ ${ }^{3}$ Institute of Bioorganic Chemistry, Polish Academy of Sciences, 61-704 Poznan, Poland
}

\begin{abstract}
Leishmania and other trypanosomatids are early eukaryotes that possess unusual molecular features, including polycistronic transcription and trans-splicing of pre-mRNAs. The spliced leader RNA (SL RNA) is joined to the $5^{\prime}$ end of all mRNAs, thus donating a $5^{\prime}$ cap that is characterized by complex modifications. In addition to the conserved $\mathrm{m}^{7} \mathrm{GTP}$, linked via a $5^{\prime}-5^{\prime}-$ triphosphate bound to the first nucleoside of the mRNA, the trypanosomatid $5^{\prime}$ cap includes $2^{\prime}$ - $O$ methylations on the first four ribose moieties and unique base methylations on the first adenine and the fourth uracil, resulting in the cap-4 structure, $\mathrm{m}^{7} \mathrm{Gpppm}_{3}{ }^{6,6,2^{\prime}} \mathrm{Apm}^{2} \mathrm{Apm}^{2} \mathrm{Cpm}_{2}{ }^{3,2^{\prime} \mathrm{U}}$, as reported elsewhere previously. A library of analogs that mimic the cap structure to different degrees has been synthesized. Their differential affinities to the cap binding proteins make them attractive compounds for studying the molecular basis of cap recognition, and in turn, they may have potential therapeutic significance. The interactions between cap analogs and eIF4E, a cap-binding protein that plays a key role in initiation of translation, can be monitored by measuring intrinsic fluorescence quenching of the tryptophan residues. In the present communication we describe the multistep synthesis of the trypanosomatid cap-4 structure. The $5^{\prime}$ terminal mRNA tetranucleotide fragment $\left(\mathrm{pm}_{3}{ }^{6,6,2^{\prime}} \mathrm{Apm}^{2} \mathrm{Apm}^{2} \mathrm{Cpm}_{2}{ }^{\left.3,2^{\prime} \mathrm{U}\right)}\right.$ was synthesized by the phosphoramidite solid phase method. After deprotection and purification, the $5^{\prime}$-phosphorylated tetranucleotide was chemically coupled with $\mathrm{m}^{7} \mathrm{GDP}$ to yield the cap-4 structure. Biological activity of this newly synthesized compound was confirmed in binding studies with elF4E from Leishmania that we recently cloned (LeishIF4E-1), using the fluorescence time-synchronized titration method.
\end{abstract}

Keywords: cap-4; chemical synthesis; Leishmania; eIF4E; fluorescence

\section{INTRODUCTION}

Leishmania and other trypanosomatids belong to the order Kinetoplastida and lead a digenetic life cycle, migrating between invertebrate vectors and mammalian hosts. They reside as promastigotes in the alimentary canal of sand fly females that transmit them to a mammalian host during their blood meal. Upon transmission, the parasites enter macrophages and cells of the immune system where they transform into amastigotes and become obligatory intracellular organisms. Leishmania parasites cause a wide spectrum of diseases, ranging from the self-healing skin lesions to the lethal visceral disease.

Reprint requests to: Edward Darzynkiewicz, Department of Biophysics, Institute of Experimental Physics, Warsaw University, 93 Zwirki and Wigury St., 02-089 Warsaw, Poland; e-mail: edek@biogeo.uw.edu.pl; fax: 48-22-72 14787.

Article published online ahead of print. Article and publication date are at http://www.rnajournal.org/cgi/doi/10.1261/rna.7510504.
Trypanosomatids are early eukaryotic protozoans that possess unique molecular features. Their RNA pol II genes are transcribed polycistronically, and the pre-mRNAs are further processed to monocistronic molecules by transsplicing and polyadenylation. During trans-splicing, a conserved capped spliced leader RNA (SL RNA) is donated to the $5^{\prime}$ end of all mRNAs. Cap biogenesis in trypanosomatids proceeds by posttranscriptional addition of the consensus $\mathrm{m}^{7} \mathrm{GTP}$, and is followed by modifications on the first four transcribed nucleotides. These include the addition of $2^{\prime}$-O methyl groups on all four ribose moieties and unique base methylations on the first adenosine and the fourth uridine. The resulting cap, $\mathrm{m}^{7} \mathrm{Gpppm}_{3}{ }^{6,6,2^{\prime}} \mathrm{Apm}^{2^{\prime}} \mathrm{Apm}^{2^{\prime}}$ $\mathrm{Cpm}_{2}{ }^{3,2^{\prime}} \mathrm{U}$, is denoted cap-4 and is found on the $5^{\prime}$ end of all mRNA molecules in all trypanosomatids (Bangs et al. 1992).

The $5^{\prime}$ cap structure in eukaryotes, as well as in trypanosomatids, participates in a variety of biological mechanisms, including mRNA transport between the nucleus and the cytoplasm, control of mRNA stability, and formation of the 

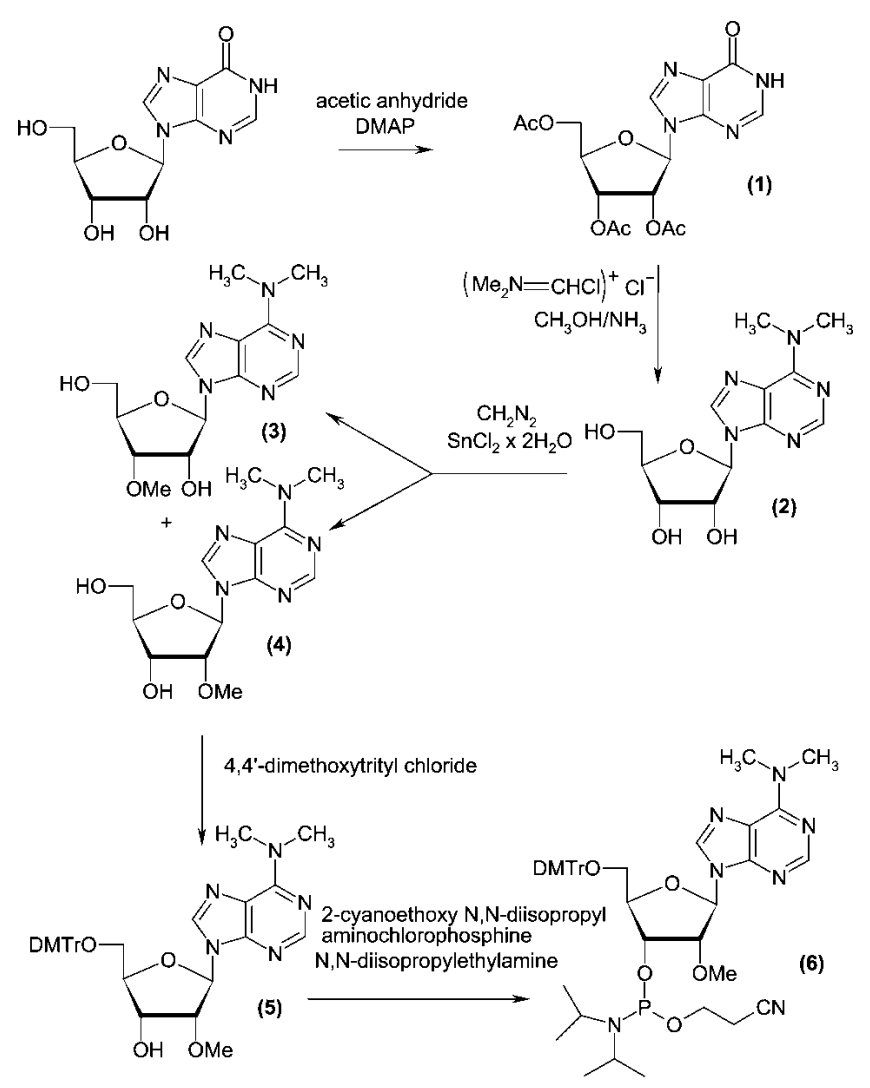

DMAP = 4-dimethylaminopyridine

FIGURE 1. Chemical synthesis of $5^{\prime}$-O-dimethoxytrityl- $N^{6}, N^{6}, O^{2}$ trimethyladenosine- $3^{\prime}$ - $O$-[(2-cyanoethyl)-( $N, N$-diisopropyl $\left.)\right]$ phosphoramidite.

translation initiation complex (Varani 1997). The general translation factor eIF4E binds the $5^{\prime}$ cap, and is part of a larger complex, eIF4F, that recruits the small ribosomal subunit (Gingras et al. 1999). Thus, the addition of synthetic $\mathrm{m}^{7} \mathrm{GTP}$ inhibits translation in an in vitro system very efficiently (Cai et al. 1999). The interaction between $\mathrm{m}^{7} \mathrm{GTP}$ and purified eIF4E can be followed by a biophysical method that monitors fluorescence quenching of Trp residues found in the cap-binding proteins (Carberry et al. 1989; Blachut-Okrasinska et al. 2000; Niedzwiecka et al. 2002). A library of cap analogs was synthesized and examined for their ability to bind eIF4E and to inhibit translation in vitro (Cai et al. 1999). Such compounds, once they penetrate the cells, could be used to inhibit translation in vivo. Synthetic analogs were also used to discriminate between the binding specificities of the different eIF4E isoforms in the nematode Caenorhabditis elegans (Miyoshi et al. 2002).

An eIF4E homolog from Leishmania was cloned and expressed in bacteria. Although the cloned gene showed only $43 \%$ similarity with the mouse eIF4E, the recombinant protein, LeishIF4E-1, bound the eukaryote $\mathrm{m}^{7} \mathrm{GTP}$ very efficiently, allowing its purification to homogeneity over $\mathrm{m}^{7}$ GTP-Sepharose (Y. Yoffe, J. Zuberek, M. Lewdorowicz,
Z. Zeira, Ch. Keasar, B. Shaanan, I. Orr-Dahan, M. Jankowska-Anyszka, E. Darzynkiewicz, and M. Shapira, in prep.). In an attempt to determine whether and how the modifications on the first four nucleotides of the Leishmania cap-4 structure affect its binding to the eIF4E isoforms, we prepared a synthetic cap- 4 analog.

Chemical synthesis of the $5^{\prime}$-phosphorylated tetranucleotide mRNA fragment was achieved by the phosphoramidite solid phase method. For the final step of the capping reaction we developed a new strategy, which included coupling of 7-methylguanosine 5' -diphosphate imidazolide (Sawai et al. 1999; Jemielity et al. 2003) with a 5'-phosphorylated tetranucleotide, in the presence of zinc chloride as a catalyst. This coupling approach appeared to be more efficient than that one reported previously (Zuberek et al. 2002, 2003).

\section{RESULTS AND DISCUSSION}

\section{Chemical synthesis}

The 5'-phosphorylated tetramer $\left(\mathrm{pm}_{3}{ }^{6,6,2^{\prime}} \mathrm{Apm}^{2^{\prime}} \mathrm{Apm}^{2^{\prime}}\right.$ $\mathrm{Cpm}_{2}{ }^{3,2^{\prime}} \mathrm{U}$, compound 13, where $\mathrm{m}$ denotes methyl groups within nuclotide units), the key intermediate for the synthesis of $5^{\prime}$-terminal cap of Leishmania $\left(\mathrm{m}^{7} \mathrm{Gpppm}_{3}{ }^{6,6,2^{\prime}}\right.$ $\mathrm{Apm}^{2 \prime} \mathrm{Apm}^{2{ }^{\prime}} \mathrm{Cpm}_{2}^{3,2^{\prime}} \mathrm{U}$, Cap-4, compound 15) was pre-

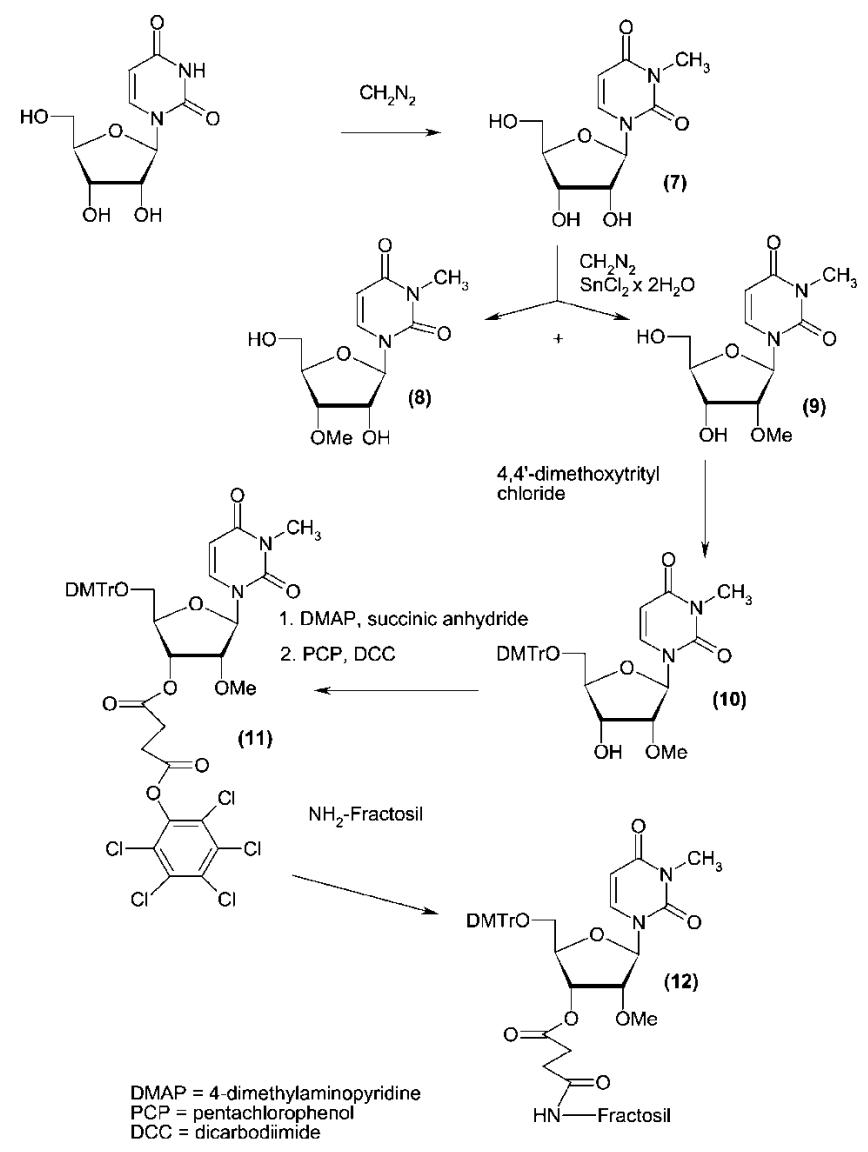

FIGURE 2. Chemical synthesis of the uridine derivative attached to the resin. 
pared by the standard phosphoramidite solid phase method (Beaucage and Caruthers 1981). However two of the four protected monomers, that is, $N^{6}, N^{6}, O^{2^{\prime}}$-trimethyladenosine and $\mathrm{N}^{3}, \mathrm{O}^{2^{\prime}}$-dimethyluridine are not commercially available. Synthesis of $N^{6}, N^{6}, O^{2^{\prime}}$-trimethyladenosine (compound 4) and its derivatization to the suitable building block (compound 6) for solid phase synthesis are shown in Figure 1. The synthetic route included (1) introduction of the $\mathrm{N}^{6}, \mathrm{~N}^{6}$-dimethylamino group into adenosine following previously published protocols (Zemlicka and Sorm 1965; Morris et al. 1976), (2) O' -methylation (Robins et al. 1974), (3) 5'-O-dimethoxytritylation (Sproat and Lamond 1991), and (4) activation with a phosphoramidite reagent (Kierzek et al. 1986; Scaringe et al. 1990; Sproat and Lamond 1991). The other unique structure, $\mathrm{N}^{3}, \mathrm{O}^{2^{\prime}}$-dimethyluridine (compound 9) was prepared in a one-pot methylation of uridine that included (1) the reaction of uridine with diazomethane to give $N^{3}$-uridine (compound 7; Szer and Shugar 1968), (2) subsequent methylation of the $\mathrm{O}^{2^{\prime}}$ and $\mathrm{O}^{3^{\prime}}$ positions with the same reagent, after addition of stannous chloride as a catalyst (Robins et al. 1974), and (3) HPLC separation of $N^{3}, \mathrm{O}^{2^{\prime}}$-dimethyluridine and $N^{3}, O^{3^{\prime}}$-dimethylridine mixture. The protection of compound 9 in the $\mathrm{O}^{5^{\prime}}$ position with dimethoxytrityl group gave $5^{\prime}$-O-dime-thoxytrityl- $N^{3}, O^{2^{\prime}}$-dimethyluridine (compound 10), which was attached to the solid support using standard methodology (Kierzek et al. 1986; Sproat and Lamond 1991) based on a succinic linker (Fig. 2). The resulting resin was used as the starting material in the automated solid phase synthesis. After two subsequent coupling stages, which added $\mathrm{O}^{2^{\prime}}$-methylcytidine and $\mathrm{O}^{2^{\prime}}$-methyladenosine, the fourth nucleoside subunit $\left(N^{6}, N^{6}, O^{2^{\prime}}\right.$-trimethyladenosine, compound 6) was attached. The last step of the solid phase synthesis involved phosphorylation of the tetranucleotide $5^{\prime}$ end with 2-cyanoethyl-3-(4,4' - dimethoxytrityloxy)-2,2-di(ethoxycarbonyl)propyl-1-N,N-diisopropyl phosphoramidite (Guzaev et al. 1995). Conventional ammonolysis was used to cleave the RNA tetramer from the solid support, resulting with the simultaneous removal of the protecting groups from the nucleic bases and intranucleotide phosphates. The resulting product, still selectively protected at the $5^{\prime}$-phosphate, was separated from impurities by preparative reverse phase HPLC. Successive detritylation with $80 \%$ acetic acid and a brief treatment with methylamine generated an RNA tetramer with a free $5^{\prime}$-phosphate group, which was purified by preparative HPLC. The final capping reaction was
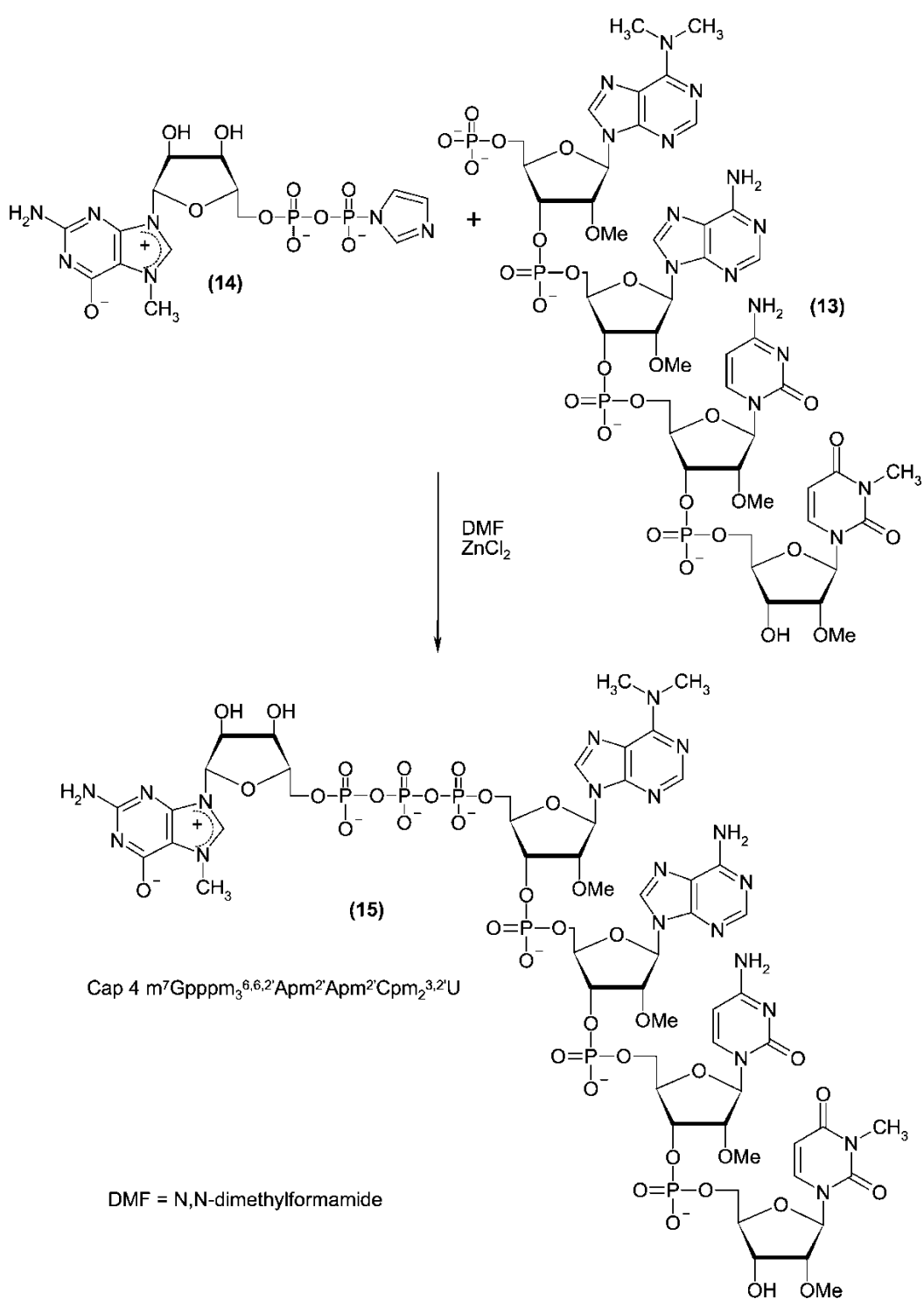

FIGURE 3. Chemical synthesis of cap-4.

performed by a method that was newly developed in our laboratory. It included coupling of the $5^{\prime}$-phosphorylated tetramer with an imidazolide derivative of 7-methylguanosine $5^{\prime}$-diphosphate $\left[\operatorname{Im}\left(\mathrm{m}^{7} \mathrm{GDP}\right)\right]$, in the presence of anhydrous zinc chloride as a catalyst, dissolved in DMF (Fig. 3). Comparable yields of capped oligoribonucleotides were reported for a similar capping strategy that was performed in water and in the presence of manganese(II) ions (Sawai at al. 1999); however, a larger excess of $\operatorname{Im}\left(\mathrm{m}^{7} \mathrm{GDP}\right)$ was used in that case. We also found the new coupling method to be superior in terms of yield and reproducibility over the previously reported method (Zuberek et al. 2002, 2003), which involved activation of a $5^{\prime}$-phosphorylated oligoribonucleotide with imidazole and its coupling with $\mathrm{m}^{7} \mathrm{GDP}$.

To perform more profound structure-function studies we also synthesized the $5^{\prime}$-terminal dinucleoside triphos- 


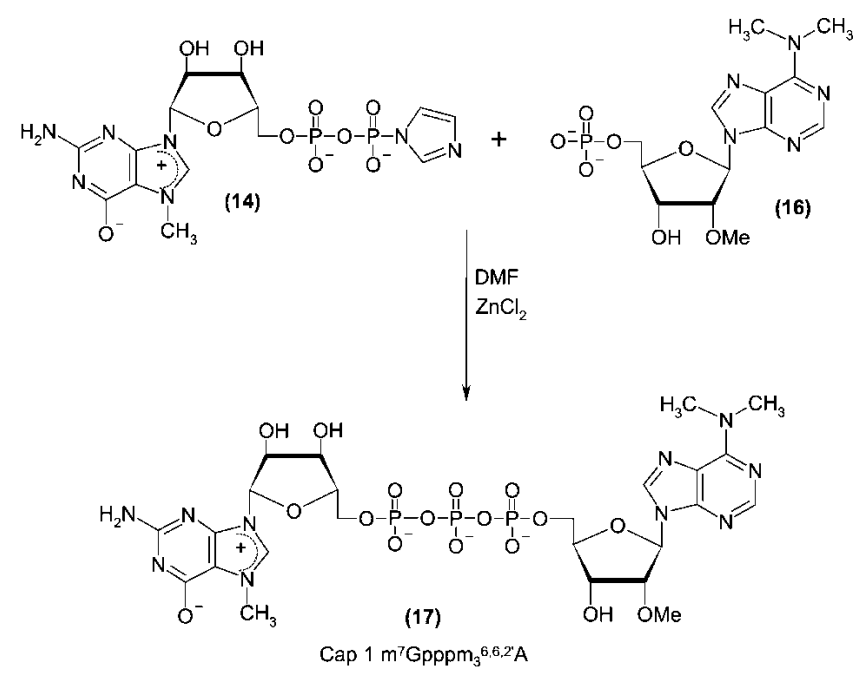

FIGURE 4. Chemical synthesis of cap-1.

phate $\mathrm{m}^{7} \mathrm{Gpppm}_{3}{ }^{6,6,2^{\prime}} \mathrm{A}$, denoted cap-1 (compound 17; Fig. 4). The synthesis was carried out in solution, using a strategy that was similar to that developed previously (Stepinski et al. 2001; Jemielity et al. 2003). The synthetic route included preparation of $N^{6}, N^{6}, O^{2}$-trimethyladenosine (compound 4; Fig. 1) from inosine, its $5^{\prime}$-phosphorylation by the Yoshikawa procedure (Yoshikawa 1967), and a final coupling performed with $\operatorname{Im}\left(\mathrm{m}^{7} \mathrm{GDP}\right)$ (Fig. 4).

The structure of the newly synthesized cap-4 was confirmed by NMR spectroscopy and mass spectrometry (ESI MS) as well as careful NMR analysis of all monomer units. The key intermediates of the synthesis were isolated and analyzed by NMR and MS (for details, see Materials and Methods).

\section{LeishIF4E-1 binds $m^{7}$ GTP and cap-4}

Purification of LeishIF4E-1 was based on its ability to bind $\mathrm{m}^{7}$ GTP. The recombinant protein was purified by $\mathrm{m}^{7}$ GTPSepharose affinity column chromatography, using a singlestep procedure. Pellets of bacteria that were induced to express LeishIF4E-1 were loaded onto a column of $\mathrm{m}^{7}$ GTPSepharose. Only washes containing free $\mathrm{m}^{7} \mathrm{GTP}$ and not GTP released LeishIF4E-1 from the column matrix (Fig. 5). For the fluorescence studies, elution was performed with high salt, rather than with the free ligand, resulting in a similar degree of purification.

To validate that the synthetically prepared cap- 4 compound was biologically active, its ability to interact with the cap-binding protein from Leishmania was examined. Studies on the tertiary structure of eIF4E from different organisms illustrate the structural basis for cap recognition, and indicate a requirement for several conserved Trp residues (Marcotrigiano et al. 1997; Matsuo et al. 1997; Tomoo et al. 2003). Binding of the cap structure and its analogs results in quenching of the Trp fluorescence, and this can be used as a tool to calculate the $\mathrm{K}_{\mathrm{as}}$ values (Carberry et al. 1989; Niedzwiecka et al. 2002). Because seven out of eight Trp residues are conserved between LeishIF4E-1 and eIF4E from mouse and yeast (Y. Yoffe, J. Zuberek, M. Lewdorowicz, Z. Zeira, Ch. Keasar, B. Shaanan, I. Orr-Dahan, M. Jankowska-Anyszka, E. Darzynkiewicz, and M. Shapira, in prep.), fluorescence assays were used to evaluate the binding affinity of LeishIF4E-1 with different cap structures.

$\mathrm{K}_{\mathrm{as}}$ values for complexes of LeishIF4E-1 with the synthetic cap analogs were determined by the fast and accurate time-synchronized fluorescence titration method (TST; Niedzwiecka et al. 2002; Fig. 6; Table 1). This method takes into account the emission of the free cap analog and the concentration of the active protein, as free parameters of the numerical fitting. The $\mathrm{K}_{\mathrm{as}}$ values determined for cap- 4 and $\mathrm{m}^{7}$ GTP were comparable, with a slight preference for cap-4 $\left(\mathrm{K}_{\mathrm{as}}=0.253 \pm 0.003 \mu \mathrm{M}^{-1}\right.$ for cap- 4 , and $\mathrm{K}_{\mathrm{as}}=0.156 \pm$ $0.005 \mu \mathrm{M}^{-1}$ for $\mathrm{m}^{7} \mathrm{GTP}$ ). These results emphasize that the synthetic cap- 4 compound was efficiently recognized by the corresponding LeishIF4E-1. Examination of $\mathrm{K}_{\mathrm{as}}$ values measured for analogs that represent intermediate compounds in cap- 4 biosynthesis revealed that the binding affinity decreased by three- to fourfold, as compared to cap-4 $\left(\mathrm{K}_{\mathrm{as}}=0.0724 \pm 0.002 \mu \mathrm{M}^{-1}\right.$ for $\mathrm{m}^{7} \mathrm{GpppA}$ and $\mathrm{K}_{\mathrm{as}}=$ $0.0654 \pm 0.0041 \mu \mathrm{M}^{-1}$ for $\mathrm{m}^{7} \mathrm{Gpppm}_{3}{ }^{6,6,2^{\prime}} \mathrm{A}$; Table 1). A reduced $\mathrm{K}_{\mathrm{as}}$ for dinucleotide analogs was previously reported for other eIF4E proteins as well (Niedzwiecka et al. 2002). Multiple eIF4E homologs that exist in lower eukaryotes such as C. elegans show differential binding characteristics to $\mathrm{m}^{7} \mathrm{GTP}$ and the hypermethylated $\mathrm{m}_{3}^{2,2,7} \mathrm{GTP}$ (TMG). Some show exclusive binding with $\mathrm{m}^{7} \mathrm{GTP}$ (IFE-3) whereas

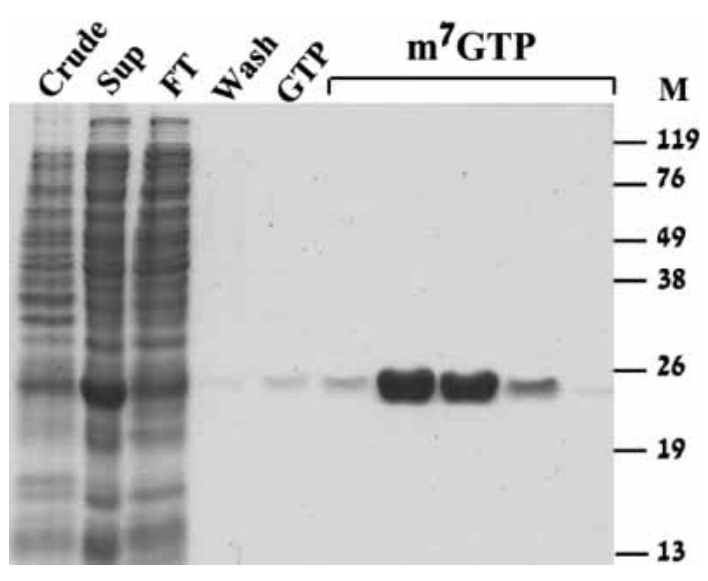

FIGURE 5. Chromatography and purification of LeishIF4E-1 on $\mathrm{m}^{7} \mathrm{GTP}$-sepharose. Crude extracts from noninduced BL21 bacterial cells (crude) and the soluble fraction (Sup) following induction by IPTG were applied onto a column of $\mathrm{m}^{7} \mathrm{GTP}$-Sepharose. The flowthrough (FT) was collected and the column was washed (Wash) first with equilibration buffer and then with equilibration buffer containing GTP $(100 \mu \mathrm{M})$. The protein was eluted by a wash containing $\mathrm{m}^{7} \mathrm{GTP}$ $(200 \mu \mathrm{M})$. 


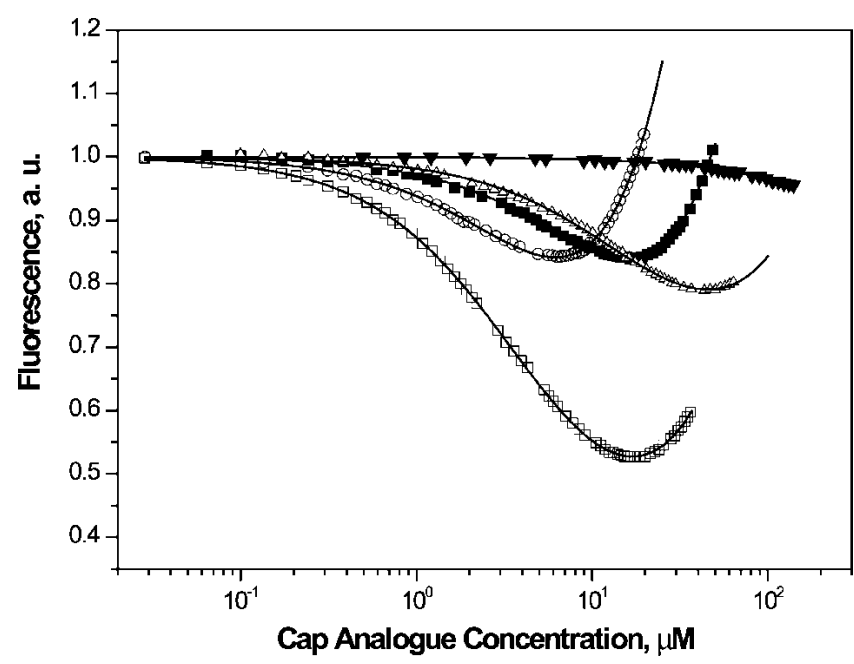

FIGURE 6. Fluorescence titration measurements on binding of LeishIF4E-1 to cap analogs. LeishIF4E-1 proteins, at a concentration of $0.3 \mu \mathrm{M}$, were titrated by the cap analogs: cap-4 (open squares), $\mathrm{m}^{7} \mathrm{GTP}$ (open circles), $\mathrm{m}^{7}$ GpppA (black squares), $\mathrm{m}^{7} \mathrm{Gpppm}_{3}{ }^{6,6,2^{\prime}} \mathrm{A}$ (open triangles), and GTP (black triangles), at $20^{\circ} \mathrm{C}$ in $50 \mathrm{mM} \mathrm{HEPES/}$ $\mathrm{NaOH}, 100 \mathrm{mM} \mathrm{NaCl}, 1 \mathrm{mM}$ EDTA, $1 \mathrm{mM}$ DTT. Protein fluorescence, presented as relative values, was excited at $295 \mathrm{~nm}$ and observed at $345 \mathrm{~nm}$. The observed increasing fluorescence intensity at a higher concentration of ligand originates from the emission of the free cap analogs in solution.

others bind both structures (IFE-5; Miyoshi et al. 2002). LeishIF4E-1 does not bind TMG (Y. Yoffe, J. Zuberek, M. Lewdorowicz, Z. Zeira, Ch. Keasar, B. Shaanan, I. OrrDahan, M. Jankowska-Anyszka, E. Darzynkiewicz, and M. Shapira, in prep.), and binds both $\mathrm{m}^{7} \mathrm{GTP}$ and cap-4 with almost similar affinities, with a slight preference for the parasite cap-4. Thus it appears that $\mathrm{m}^{7} \mathrm{GTP}$ may play a key role in the interaction between LeishIF4E-1 and cap-4, and the remaining modified nucleotides possibly contribute to the additional specificity of binding.

Synthetically prepared cap analogs provide an important research tool for establishing the structural basis of cap recognition by the corresponding binding proteins. To date, the role of the unique and complex cap found in trypanosomatids is only partially understood. Cap formation on the SL RNA proceeds in a $5^{\prime}-3^{\prime}$ direction, as indicated by experiments performed with permeable trypanosomes (Ullu and Tschudi 1995). It appears that at least part of the modifications occur cotranscriptionally, as shown in studies using permeable trypanosomes (Mair et al. 2000) and that sequences within the SL RNA coding gene are required for obtaining the complete cap- 4 structure (Ullu and Tschudi 1995; Zeiner et al. 2003). However, it was recently shown that the cytoplasmic stage is necessary for SL RNA biogenesis (Zeiner et al. 2003). It was further suggested that U4 modification of the SL RNA most probably serves as a signal for transport of snRNPs between the nucleus and the cytoplasm (Mandelboim et al. 2003). The availability of a synthetic and functional cap-4, as well as its intermediate com- pounds, is therefore of great importance. Such materials should also contribute to the identification of enzymes that participate in cap- 4 biogenesis and in turn, could serve as a basis for the development of new therapeutic molecules, with antiparasitic activity.

The ability to chemically synthesize an analog of cap-4, a structure that is found on the $5^{\prime}$ end of mRNAs in all trypanosomatids, is of great importance. Trypanosomatids are known for their unusual molecular mechanisms, and it has been well established that differential gene expression in these organisms is achieved by posttranscriptional mechanisms such as processing and translation of mRNAs (Zilka et al. 2001). The $5^{\prime}$ cap has a key role in directing these processes in all eukaryotes including in trypanosomatids, but the latter possess a unique cap-4 structure that is found only in this group of organisms. Thus the availability of this synthetic structure as well as its intermediates is essential for identifying the components that participate in the biosynthetic pathway of cap-4. Once identified, such molecules, in principle, could be used as novel drug targets against Leishmania as well as other trypanosomatid parasites.

\section{MATERIALS AND METHODS}

\section{Monitoring of the chemical synthesis}

TLC analysis was performed on TLC plates coated with silicagel 60 F-254 (Merck), developed by chloroform-methanol-triethylamine 8.9:1:0.1 v/v/v (A), hexane-acetone-triethylamine 45:45:10 v/v/v (B), chloroform-methanol 8:2 v/v (C), dichloromethane-methanol 95:5 v/v (D).

Analytical HPLC was performed on a Spectra-Physics SP8800 apparatus, using a Supelcosil LC-18-T reverse phase column $(4.6 \times 250 \mathrm{~mm}$, flow rate $1.3 \mathrm{~mL} / \mathrm{min})$ with various gradients of buffer A (0.05 M ammonium acetate at $\mathrm{pH} 5.9)$ and buffer $\mathrm{B}$ (methanol and buffer A, 1:1 v/v).

${ }^{1} \mathrm{H}$ NMR and ${ }^{13} \mathrm{C}$ NMR spectra were run on a Varian UNITYplus spectrometer at 400 and $100.56 \mathrm{MHz}$, respectively, at ambient temperatures and at concentrations of ca. $2 \mathrm{mg} / \mathrm{mL}\left({ }^{1} \mathrm{H} \mathrm{NMR}\right)$, and ca. $20 \mathrm{mg} / \mathrm{mL}\left({ }^{13} \mathrm{C} \mathrm{NMR}\right)$ using tetramethylsilane (TMS) as the internal standard in $\mathrm{CDCl}_{3}$ and sodium 3-trimethylsilyl$\left[2,2,3,3-\mathrm{D}_{4}\right]$-propinonate (TSP) in $\mathrm{D}_{2} \mathrm{O}$.

Mass spectra were recorded on a Micromass QToF 1 MS spectrometer using electrospray ionization.

TABLE 1. The equilibrium association constants $\left(\mathrm{K}_{\mathrm{as}}\right)$ for complexes of LeishIEF4-1 with cap-4 and other cap analogs at $20^{\circ} \mathrm{C}$ determined by fluorescence measurements

\begin{tabular}{lc}
\hline Cap analogs & $\mathrm{K}_{\text {as }}(\mu \mathrm{M})^{-1}$ \\
\hline $\mathrm{m}^{7} \mathrm{GTP}$ & $0.156 \pm 0.005$ \\
$\mathrm{~m}^{7} \mathrm{GpppA}$ & $0.0724 \pm 0.0020$ \\
$\mathrm{~m}^{7} \mathrm{Gpppm}{ }^{6,6,2^{\prime}} \mathrm{A}$ & $0.0654 \pm 0.0041$ \\
cap-4 & $0.253 \pm 0.003$ \\
$\mathrm{GTP}$ & $<0.005$ \\
\hline
\end{tabular}




\section{Preparative HPLC}

Preparative HPLC was performed on a Waters 600E Multisolvent Delivery System apparatus, using a Waters HR-C-18 reverse phase column $(19 \times 300 \mathrm{~mm}$, flow rate $5.0 \mathrm{~mL} / \mathrm{min})$. The mobile phase for this method was the same as for analytical HPLC (see above).

\section{$2^{\prime}, 3^{\prime}, 5^{\prime}$-tri-O-acetylinosine (compound 1)}

Inosine ( $2 \mathrm{~g}, 7.5$ mmoles $)$ and $\mathrm{N}, \mathrm{N}$-dimethylaminopyridine $(0.150$ g, 1.23 mmoles) were added to acetic anhydride $(87 \mathrm{~mL})$, and the mixture was stirred for $3 \mathrm{~d}(72 \mathrm{~h})$ at room temperature. The progress of the reaction was monitored by HPLC $\left(\mathrm{Rt}_{\text {substrate }}=2.9\right.$ min, $\mathrm{Rt}_{\text {product }}=27 \mathrm{~min}$, in buffer $\mathrm{B}$ ). The solution was evaporated under reduced pressure at $30^{\circ} \mathrm{C}$ and the residue was coevaporated with three portions of ethanol $(30 \mathrm{~mL})$. The resulting colorless solid material was crystallized from $20 \mathrm{~mL}$ of hot ethanol to give $2^{\prime}, 3^{\prime}, 5^{\prime}$-tri-O-acetylinosine (compound 1; $2.382 \mathrm{~g}, 6$ mmoles, $80 \%)$.

\section{$\mathrm{N}^{6}, \mathrm{~N}^{6}$-dimethyladenosine (compound 2)}

A mixture of $2^{\prime}, 3^{\prime}, 5^{\prime}$-tri-O-acetylinosine (compound 1; $4.5 \mathrm{~g}, 11.4$ mmoles), (chloromethylene)dimethylammonium chloride (10 g, $78 \mathrm{mmoles})$ and chloroform $(35 \mathrm{~mL})$ was refluxed during $2 \mathrm{~h}$. This procedure resulted in a reaction mixture that contained the main product, $2^{\prime}, 3^{\prime}, 5^{\prime}$-Tri-O-acetyl-6-chloro-9-( $\beta$-D-ribofuranosyl)purine, with only traces of the starting material. The progress of the reaction was monitored by HPLC $\left(\mathrm{Rt}_{\text {substrate }}=27 \mathrm{~min}\right.$, $\mathrm{Rt}_{\text {product }}=25 \mathrm{~min}$, in buffer $\mathrm{B}$ ). The mixture was allowed to cool and sodium hydrogen carbonate (6 g, 71 mmoles) in water (26 $\mathrm{mL}$ ) was then added dropwise. The aqueous layer was extracted with chloroform $(3 \times 15 \mathrm{~mL})$ and the chloroform layers were combined, dried over anhydrous sodium sulphate, filtered, and evaporated under reduced pressure. (Chloromethylene)dimethylammonium chloride ( $5.3 \mathrm{~g}, 41 \mathrm{mmoles}$ ) in chloroform $(15 \mathrm{~mL})$ was then added to this residue, and the resulting mixture was added dropwise with cooling and stirring into a solution of methanolic ammonia. Solvents were evaporated under reduced pressure and the residue was washed with chloroform. The solid phase was filtered off and the filtrate was evaporated under reduced pressure. Methanolic ammonia solution was added to the residual syrup, and the mixture was kept at $0^{\circ} \mathrm{C}$ during $17 \mathrm{~h}$. The resulting solution was then evaporated under reduced pressure and the residue was recrystallized from ethanol to yield $N^{6}, N^{6}$-dimethyladenosine (compound 2; $2.2 \mathrm{~g}, 7.4$ mmoles, 65\%).

$\mathrm{N}^{6}, \mathrm{~N}^{6}, \mathrm{O}^{2^{\prime}}$-trimethyladenosine (compound 4) and $\mathrm{N}^{6}, \mathrm{~N}^{6}, \mathrm{O}^{3^{\prime}}$-trimethyladenosine (compound 3)

$N^{6}, N^{6}$-dimethyladenosine (compound 2) (2 g, 6.8 mmoles) and stannous chloride dihydrate $(0.067 \mathrm{~g}, 0.3 \mathrm{mmoles})$ in methanol $(540 \mathrm{~mL})$ were stirred at room temperature. A solution of diazomethane in 1,2-dimethoxyethane (0.43 M; Robins et al. 1974) was slowly added into this mixture and the progress of the reaction was monitored by TLC. When the starting material disappeared (after about $3 \mathrm{~h}$ ), the solvent was evaporated under reduced pressure. The residue was dissolved in $25 \%$ aqueous methanol and purified by column chromatography $(50 \times 2 \mathrm{~cm}, 110 \mathrm{~mL}$, Dowex $1 \mathrm{X} 2$ in $\mathrm{OH}^{-}$form, fractions of $23 \mathrm{~mL}$ each were collected), performed in the same solvent. Fractions 33-47 contained $N^{6}, N^{6}, O^{2}$-trimethyladenosine (compound 4; $0.688 \mathrm{~g}, 2.2$ mmoles, $34 \%, \mathrm{R}_{\mathrm{f}}=0.1$ in system A): ${ }^{1} \mathrm{H}$ NMR $\left(\mathrm{CDCl}_{3}, \delta \mathrm{ppm}\right): 8.31(1 \mathrm{H}, \mathrm{H} 8 \mathrm{~s}), 7.79(1 \mathrm{H}$, $\mathrm{H} 2 \mathrm{~s}), 5.85\left(1 \mathrm{H}, \mathrm{H} 1^{\prime} \mathrm{d}, \mathrm{J}=7.6 \mathrm{~Hz}\right), 4.67\left(1 \mathrm{H}, \mathrm{H} 2^{\prime} \mathrm{q}, \mathrm{J}=4.67 \mathrm{~Hz}\right)$, $3.65\left(2 \mathrm{H}, \mathrm{H} 5^{\prime}, 5^{\prime \prime} \mathrm{m}\right), 4.57\left(1 \mathrm{H}, \mathrm{H} 3^{\prime} \mathrm{d}, \mathrm{J}=4.67 \mathrm{~Hz}\right), 3.45(6 \mathrm{H}$, $\left.\mathrm{N}-\left(\mathrm{CH}_{3}\right)_{2} \mathrm{~m}\right), 4.33\left(1 \mathrm{H}, \mathrm{H}^{\prime} \mathrm{s}\right), 3.25\left(3 \mathrm{H}, \mathrm{O}-\mathrm{CH}_{3} \mathrm{~s}\right)$.

Fractions 54-102 contained $N^{6}, N^{6}, O^{3^{\prime}}$-trimethyladenosine (compound 3; $1.1 \mathrm{~g}, 3.5$ mmoles, $52 \%, \mathrm{R}_{\mathrm{f}}=0.1$ in system $\mathrm{A}$ ): ${ }^{1} \mathrm{HNMR}\left(\mathrm{CDCl}_{3}, \delta \mathrm{ppm}\right): 8.21(1 \mathrm{H}, \mathrm{H} 2 \mathrm{~s}), 7.73(1 \mathrm{H}, \mathrm{H} 8 \mathrm{~s}), 5.67$ $\left(1 \mathrm{H}, \mathrm{H} 1^{\prime} \mathrm{d}, \mathrm{J}=7.6 \mathrm{~Hz}\right), 5.03\left(1 \mathrm{H}, \mathrm{H} 2^{\prime} \mathrm{t}, \mathrm{J}=6.2 \mathrm{~Hz}\right), 4.34\left(1 \mathrm{H}, \mathrm{H} 4^{\prime}\right.$ s), $4.06\left(1 \mathrm{H}, \mathrm{H}^{\prime} \mathrm{d}, \mathrm{J}=5.6 \mathrm{~Hz}\right), 3.80\left(2 \mathrm{H}, \mathrm{H} 5^{\prime}, 5^{\prime \prime} \mathrm{m}\right), 3.53(3 \mathrm{H}$, $\left.\mathrm{O}-\mathrm{CH}_{3} \mathrm{~s}\right), 3.50\left(6 \mathrm{H}, \mathrm{N}-\left(\mathrm{CH}_{3}\right)_{2}\right.$ broad s).

$5^{\prime}$-O-dimethoxytrityl- $\mathrm{N}^{6}, \mathrm{~N}^{6}, \mathrm{O}^{2^{\prime}}$-trimethyladenosine (compound 5)

A mixture of $N^{6}, N^{6}, O^{2^{\prime}}$-trimethyladenosine (compound 4; 0.460 g, 1.5 mmoles), 4,4' -dimethoxytrityl chloride (1.5 g, 4.4 mmoles) and triethylamine $(0.587 \mathrm{~mL})$ in anhydrous pyridine $(8 \mathrm{~mL})$ was stirred for $2 \mathrm{~h}$ at room temperature, and the progress of the reaction was monitored by TLC. The mixture was quenched with methanol $(1.5 \mathrm{~mL})$ and evaporated under reduced pressure at room temperature. The residual syrup was dissolved in chloroform $(30 \mathrm{~mL})$ and washed with two $32-\mathrm{mL}$ portions of $1 \mathrm{M}$ aqueous sodium hydrogen carbonate solution. The chloroform layer was dried over anhydrous sodium sulphate, filtered, and evaporated under reduced pressure. The residual pyridine was removed by coevaporation with three $3-\mathrm{mL}$ portions of toluene. The crude product was purified by column chromatography over silicagel, and was eluted with a stepwise gradient system $(0.25 \%-2 \%)$ of methanol in dichloromethane to give $5^{\prime}$-O-dimethoxytrityl$N^{6}, N^{6}, O^{2}$-trimethyladenosine (compound 5; $0.73 \mathrm{~g}, 1.2$ mmoles, $81 \%, \mathrm{R}_{\mathrm{f}}=0.3$ in $\mathrm{A}$ ).

$5^{\prime}$-O-dimethoxytrityl- $\mathrm{N}^{6}, \mathrm{~N}^{6}, \mathrm{O}^{2^{\prime}}$-trimethyladenosine-3' -O-[(2cyanoethyl)-(N,N-diisopropyl)]phosphoramidite (compound 6)

A mixture of $5^{\prime}$-O-dimethoxytrityl- $N^{6}, N^{6}, O^{2}$-trimethyladenosine (compound 5; $0.7 \mathrm{~g}, 1.14$ mmoles), $\mathrm{N}, \mathrm{N}$-diisopropylethylamine (0.3 mL, $1.71 \mathrm{mmoles}$ ), and 2-cyanoethoxy $N, N$-diisopropylaminochlorophosphine $(0.33 \mathrm{~mL}, 0.350 \mathrm{~g}, 1.48 \mathrm{mmoles})$ in anhydrous acetonitrile $(5 \mathrm{~mL})$ was stirred at room temperature for $1 \mathrm{~h}$. The progress of the reaction was monitored by TLC. The crude product was purified using column chromatography (silicagel, eluting with a stepwise gradient system of ethyl acetate in hexane containing $1 \%$ triethylamine [from $5 \%$ to $50 \%$ ethyl acetate]) to give $5^{\prime}$-O-dimethoxytrityl- $N^{6}, N^{6}, O^{2^{\prime}}$-trimethyladenosine-3' - $O$ - [ $(2-c y-$ anoethyl)-( $N, N$-diisopropyl) $]$ phosphoramidite (compound 6; $0.68 \mathrm{~g}$, 0.84 mmoles, $73 \%, \mathrm{R}_{\mathrm{f}}=0.4$ in system $\left.\mathrm{B}\right):{ }^{1} \mathrm{H} \mathrm{NMR}\left(\mathrm{CDCl}_{3}\right.$, $\delta$ ppm): 8.40 (1H, H2 s), 7.87 (1H, H8 d), 7.20 (9H, DMTr m), $6.80(4 \mathrm{H} \mathrm{m}, \mathrm{DMTr}), 6.16\left(1 \mathrm{H}, \mathrm{H}^{\prime}{ }^{\prime} \mathrm{t}, \mathrm{J}=5.1 \mathrm{~Hz}\right), 4.65\left(1 \mathrm{H}, \mathrm{H} 2^{\prime}\right.$ m), 4.55 (1H, H3' m), 4.27 (1H, H4' m), 3.90 (2H, H5', $\left.5^{\prime \prime} \mathrm{m}\right), 3.78$ (6H s, DMTr), $3.60\left(6 \mathrm{H} \mathrm{m}, \mathrm{N}-\left(\mathrm{CH}_{3}\right)_{2}\right), 3.50\left(3 \mathrm{H} \mathrm{s}, \mathrm{O}-\mathrm{CH}_{3}\right), 2.68$ $\left(2 \mathrm{H}, \mathrm{O}-\mathrm{CH}_{2}-\mathrm{CH}_{2}-\mathrm{CN} \mathrm{t}, \mathrm{J}=6.4 \overline{\mathrm{Hz}}\right), 2.63\left(2 \mathrm{H} \mathrm{t}, \mathrm{O}-\mathrm{CH}_{2}-\mathrm{CH}_{2}-\right.$ $\mathrm{CN}, \mathrm{J}=6.4 \mathrm{~Hz}), 1.30\left(2 \mathrm{H} \mathrm{m},\left(\mathrm{CH}_{3}\right)_{2}-\mathrm{CH}-\mathrm{N}-\mathrm{CH}-\left(\mathrm{CH}_{3}\right)_{2}\right), 1.20$ $\left(12 \mathrm{H} \mathrm{m},\left(\mathrm{CH}_{3}\right)_{2}-\mathrm{CH}-\mathrm{N}-\mathrm{CH}-\left(\mathrm{CH}_{3}\right)_{2}\right)$.

$\mathrm{N}^{3}, \mathrm{O}^{2^{\prime}}$-dimethyluridine (compound 9 ) and $\mathrm{N}^{3}, \mathrm{O}^{3^{\prime}}$-dimethyluridine (compound $\boldsymbol{8}$ )

A mixture of uridine ( $3 \mathrm{~g}, 12$ mmoles) and methanol ( $80 \mathrm{~mL})$ was stirred in a round-bottom flask at room temperature. A solution of diazomethane in 1,2-dimethoxyethane $(0.43 \mathrm{M}$; Robins et al. 
1974) was then slowly added into this mixture and the progress of the reaction was monitored by TLC. After $1 \mathrm{~h}$ all the starting material disappeared and $N^{3}$-methyluridine (compound 7) $\left(\mathrm{R}_{\mathrm{f}}=0.2\right.$ in system $\left.\mathrm{C}\right)$ dominated the reaction mixture. Stannous chloride dihydrate $(0.061 \mathrm{~g}, 0.27$ mmoles $)$ and the second portion of an ethereal solution of diazomethane were then slowly added and the reaction was completed after 1 h. Two regioisomers: $\mathrm{N}^{3}, \mathrm{O}^{2^{\prime}}$-dimethyluridine (compound 9) and $\mathrm{N}^{3}, \mathrm{O}^{3^{\prime}}$-dimethyluridine (compound 8) were separated by preparative HPLC $\left(\mathrm{Rt}_{\mathbf{8}}=35\right.$ $\min , \mathrm{Rt}_{\mathbf{9}}=38 \mathrm{~min}$, using a linear $0 \%-100 \%$ gradient of buffer $\mathrm{B}$ in buffer A within $40 \mathrm{~min}$ ) to yield $47 \%$ of $N^{3}, O^{2^{\prime}}$-dimethyluridine (compound 9) and 50\% of $\mathrm{N}^{3}, \mathrm{O}^{3^{\prime}}$-dimethyluridine (compound 8).

${ }^{1} \mathrm{H}$ NMR for $\mathrm{N}^{3}, \mathrm{O}^{2^{\prime}}$-dimethyluridine (compound 9): $\left(\mathrm{D}_{2} \mathrm{O}, \delta\right.$ ppm): $7.90(1 \mathrm{H}, \mathrm{H} 6 \mathrm{~d}, \mathrm{~J}=8.02 \mathrm{~Hz}), 6.00\left(1 \mathrm{H}, \mathrm{H} 1^{\prime} \mathrm{d}, \mathrm{J}=3.67 \mathrm{~Hz}\right)$, $5.98(1 \mathrm{H}, \mathrm{H} 5 \mathrm{~d}, \mathrm{~J}=8.02 \mathrm{~Hz}), 4.30\left(1 \mathrm{H}, \mathrm{H} 3^{\prime} \mathrm{t}, \mathrm{J}=6.01 \mathrm{~Hz}\right), 4.11$ $\left(1 \mathrm{H}, \mathrm{H} 4^{\prime} \mathrm{m}\right), 4.00\left(1 \mathrm{H}, \mathrm{H} 2^{\prime} \mathrm{t}, \mathrm{J}=3.68 \mathrm{~Hz}\right), 3.85\left(2 \mathrm{H}, \mathrm{H} 5^{\prime}, 5^{\prime \prime} \mathrm{m}\right)$, $3.54\left(3 \mathrm{H}, \mathrm{N}-\mathrm{CH}_{3}\right), 3.30\left(3 \mathrm{H} \mathrm{s}, \mathrm{O}-\mathrm{CH}_{3}\right)$.

\section{$5^{\prime}$-O-dimethoxytrityl- $\mathrm{N}^{3}, \mathrm{O}^{2}$-dimethyluridine (compound 10)}

A mixture of $\mathrm{N}^{3}, \mathrm{O}^{2^{\prime}}$-dimethyluridine (compound 9; $0.5 \mathrm{~g}, 1.8$ mmoles), 4,4'-dimethoxytrityl chloride (1.2 g, 3.5 mmoles) and triethylamine $(0.6 \mathrm{~mL})$ in anhydrous pyridine $(7 \mathrm{~mL})$ was stirred for $2 \mathrm{~h}$ at room temperature, and the progress of the reaction was monitored by TLC. The reaction was quenched with methanol $(1.5 \mathrm{~mL})$ and evaporated under reduced pressure at room temperature. The residual syrup was dissolved in chloroform $(33 \mathrm{~mL})$ and washed with two 33-mL portions of $1 \mathrm{M}$ aqueous sodium hydrogen carbonate solution. The chloroform layer was dried over anhydrous sodium sulfate, filtered, and evaporated under reduced pressure. The residual pyridine was removed by coevaporation with $3 \times 3 \mathrm{~mL}$ of toluene. The crude product was purified by column chromatography (silicagel, eluted by a stepwise gradient of methanol in dichloromethane [ranging from $0.25 \%$ to $2 \%$ methanol]), to give $5^{\prime}$-O-dimethoxytrityl- $\mathrm{N}^{3}, \mathrm{O}^{2^{\prime}}$-dimethyluridine (compound 10) $\left(0.84 \mathrm{~g}, 1.5\right.$ mmoles, $83 \%, \mathrm{R}_{\mathrm{f}}=0.7$ in system $\left.\mathrm{A}\right):{ }^{1} \mathrm{H}$ $\operatorname{NMR}\left(\mathrm{CDCl}_{3}, \delta \mathrm{ppm}\right): 8.01(1 \mathrm{H}, \mathrm{H} 6 \mathrm{~d}, \mathrm{~J}=8.00 \mathrm{~Hz}), 7.40(9 \mathrm{H} \mathrm{m}$, DMTr), 6.82 (4H m, DMTr), 5.97 (1H, H1' s), 5.35 (1H, H5 d, $\mathrm{J}=8.00 \mathrm{~Hz}), 4.46\left(1 \mathrm{H}, \mathrm{H} 3^{\prime} \mathrm{q}\right), 3.99\left(1 \mathrm{H}, \mathrm{H} 2^{\prime} \mathrm{t}, \mathrm{J}=7.89 \mathrm{~Hz}\right), 3.79$ $\left(6 \mathrm{H} \mathrm{s},-\mathrm{O}-\mathrm{CH}_{3}, \mathrm{DMTr}\right), 3.77\left(1 \mathrm{H}, \mathrm{H} 4^{\prime} \mathrm{s}\right), 3.67\left(3 \mathrm{H} \mathrm{s}, \mathrm{N}-\mathrm{CH}_{3}\right)$, $3.55\left(2 \mathrm{H}, \mathrm{H} 5^{\prime}, 5^{\prime \prime} \mathrm{m}\right), 3.32\left(3 \mathrm{H} \mathrm{s}, \mathrm{O}-\mathrm{CH}_{3}\right){ }^{13} \mathrm{C} \mathrm{NMR}\left(\mathrm{CDCl}_{3}, \delta\right.$ ppm): 162.81 (1C, C(4)=O), 158.67, 144.32, 135.31, 130.15, 129.09, 113.25, 87.00 (19C, DMTr), 150.89 (1C, C2=O), 137.62 (1C, C6), 101.42 (1C, C5), 87.60, 83.97, 83.06, 68.25, 61.05, 58.63 $\left(6 \mathrm{C}, \mathrm{Cl}^{\prime}, \mathrm{C} 2^{\prime}, \mathrm{C}^{\prime}, \mathrm{C} 4^{\prime}, \mathrm{C}^{\prime}, \mathrm{O}^{2}-\mathrm{CH}_{3}\right), 55.20\left(2 \mathrm{C}, \mathrm{O}-\mathrm{CH}_{3}\right.$, DMTr), 27.45 (1C, $\left.\mathrm{N}-\underline{\mathrm{CH}}_{3}\right)$.

\section{$5^{\prime}$-O-dimethoxytrityl- $\mathrm{N}^{3}, \mathrm{O}^{2{ }^{\prime}}$-dimethyluridine-3' -O- pentachlorophenylsuccinate (compound 11)}

A mixture of $5^{\prime}$-O-dimethoxytrityl- $N^{3}, O^{2^{\prime}}$-dimethyluridine (compound 10; $0.534 \mathrm{~g}, 0.92$ mmoles), succinic anhydride ( $0.101 \mathrm{~g}, 1.01$ mmoles), and $N, N$-dimethylaminopyridine ( $0.134 \mathrm{~g}, 1.1 \mathrm{mmoles})$ in dichloromethane $(5 \mathrm{~mL})$ was stirred for $2 \mathrm{~h}$ at room temperature. The progress of the reaction was monitored by TLC $\left(\mathrm{R}_{\mathrm{f}}=0.3\right.$ in system D). N,N-dicyclohexylocarbodiimide $(0.246 \mathrm{~g}, 1.2$ mmoles) and pentachlorophenol ( $0.270 \mathrm{~g}, 1.1 \mathrm{mmoles})$ were then added. The mixture was allowed to stand overnight and the precipitate was filtered off. The filtrate was extracted with a saturated aqueous solution of sodium dihydrogen phosphate and purified by column chromatography (silicagel). Elution was performed with a stepwise gradient $(1 \%-2 \%)$ of methanol in dichloromethane, to give $5^{\prime}$-O-dimethoxytrityl- $\mathrm{N}^{3}, \mathrm{O}^{2^{\prime}}$-dimethyluridine- $3^{\prime}$-O-pentachlorophenylsuccinate (compound 11; $0.798 \mathrm{~g}, 0.86$ mmoles, $93 \%$, $\mathrm{R}_{\mathrm{f}}=0.8$ in system D): ${ }^{1} \mathrm{H} \mathrm{NMR}\left(\mathrm{CDCl}_{3}, \delta \mathrm{ppm}\right): 7.87(1 \mathrm{H}, \mathrm{H} 6 \mathrm{~d}$, $\mathrm{J}=7.99 \mathrm{~Hz}$ ), 7.40 (9H m, DMTr), 7.30 (9H m, DMTr), $6.82(4 \mathrm{H}$ m, DMTr), $6.00\left(1 \mathrm{H}, \mathrm{H} 1^{\prime} \mathrm{d}, \mathrm{J}=3.20 \mathrm{~Hz}\right), 5.42(1 \mathrm{H}, \mathrm{H} 5 \mathrm{~d}, \mathrm{~J}=7.99$ $\mathrm{Hz}), 4.26\left(1 \mathrm{H}, \mathrm{H} 3^{\prime} \mathrm{q}\right), 4.10\left(1 \mathrm{H}, \mathrm{H} 2^{\prime} \mathrm{m}, \mathrm{J}=3.10 \mathrm{~Hz}\right), 3.78(6 \mathrm{H} \mathrm{s}$, $\left.-\mathrm{O}-\mathrm{CH}_{3}, \mathrm{DMTr}\right), 3.78\left(1 \mathrm{H}, \mathrm{H} 4^{\prime} \mathrm{s}\right), 3.52\left(2 \mathrm{H}, \mathrm{H} 5^{\prime}, 5^{\prime \prime} \mathrm{m}\right), 3.50(3 \mathrm{H}$, $\mathrm{N}-\mathrm{CH}_{3} \mathrm{~s}, \mathrm{~N}^{3}$-methyluracyl ring $), 3.32\left(3 \mathrm{H} \mathrm{s}, \mathrm{O}^{2^{\prime}}-\mathrm{CH}_{3}\right), 2.90(4 \mathrm{H}$ $\left.\mathrm{m},-\overline{\mathrm{C}}(\mathrm{O})-\mathrm{CH}_{2}-\mathrm{CH}_{2}-\mathrm{C}(\mathrm{O})-\right)$.

$5^{\prime}$-O-dimethoxytrityl- $\mathrm{N}^{3}, \mathrm{O}^{2^{\prime}}$-dimethyluridine-3'-Osuccinamide attached to the resin (compound 12)

A mixture of $5^{\prime}$-O-dimethoxytrityl- $\mathrm{N}^{3}, \mathrm{O}^{2^{\prime}}$-dimethyluridine- $3^{\prime}$-Opentachlorophenylsuccinate (compound 11; $0.150 \mathrm{~g}, 0.16$ mmoles), triethylamine $(0.4 \mathrm{~mL})$, and Fractosil 500 (1 g; Merck) in dimethylformamide $(4 \mathrm{~mL})$ was shaken overnight at room temperature. The resin was then washed successively with four portions of dichloromethane and methanol, filtered, and dried. Free $\mathrm{NH}_{2}$-groups on the resin were acetylated with acetic anhydride (1 $\mathrm{mL}), N, N$-dimethylaminopyridine $(0.010 \mathrm{~g}, 0.082 \mathrm{mmoles})$ in anhydrous pyridine $(5 \mathrm{~mL})$. The mixture was shaken for $1 \mathrm{~h}$ and then the resin was filtered off, washed successively with four portions of dichloromethane, and methanol. Afterward the resin was dried.

\section{Solid phase synthesis}

The RNA tetramer was synthesized on an Applied Biosystems 392 synthesizer using a $1 \mu$ mole scale protocol with 10 min coupling for each step. The starting material (compound 12) was placed in a standard reaction vessel and, successively, building blocks were coupled for elongation of the ribonucleic chain. $N$-Benzoyl-5' dimethoxytrityl-2' -O-methyl-cytidine-3' - [(2-cyanoethyl)-(N,Ndiisopropyl)]-phosphoramidite and $5^{\prime}$-dimethoxytrityl-2' -O-methyl$N$-phenoxyacetyladenosine- $3^{\prime}$ - [(2-cyanoethyl)-( $N, N$-diisopropyl)]phosphoramidite were commercial products (Glen Research). 5' Dimethoxytrityl- $N^{6}, N^{6}, O^{2^{\prime}}$-trimethyladenosine-3' - [(2-cyanoethyl)$(\mathrm{N}, \mathrm{N}$-diisopropyl)]-phosphoramidite was synthetically prepared (compound 6). The 5'-phosphorylating reagent 2-cyanoethyl3-(4,4'-dimethoxytrityloxy)-2,2-di(ethoxycarbonyl)propyl-1- $N, N$ diisopropyl phosphoramidite, which was employed in the last step of the automated synthesis, was purchased from Glen Research.

\section{Unprotected RNA fragment $\left(\mathrm{pm}_{3}{ }^{6,6,2^{\prime}} \mathrm{Apm}_{2^{\prime}} \mathrm{Apm}_{2^{\prime}} \mathrm{Cpm}_{2}{ }^{3,2^{\prime}} \mathrm{U}\right)$ (compound 13)}

A 5'-blocked RNA fragment (obtained from the solid phase synthesis) was detritylated for $2 \mathrm{~h}$ with $80 \%$ acetic acid. After $2 \mathrm{~h}$ acetic acid was evaporated under reduced pressure and then methylamine $(6 \mathrm{~mL})$ was added. After $15 \mathrm{~min}$, the methylamine was removed using $\mathrm{P}_{4} \mathrm{O}_{10}$ in a vacuum desiccator and the product was purified by preparative HPLC $\left(\mathrm{Rt}_{\text {product }}=16.9 \mathrm{~min}\right.$, linear $0-100 \%$ gradient of buffer $\mathrm{B}$ in buffer A over $50 \mathrm{~min})$ to give 0.021 g (0.0143 mmoles) of $\mathrm{pm}_{3}{ }^{6,6,2^{\prime}} \mathrm{Apm}^{2^{\prime}} \mathrm{Apm}^{2^{\prime}} \mathrm{Cpm}_{2}{ }^{3,2^{\prime}} \mathrm{U}$ (compound 13) as an ammonium salt (m/z 1384.6 by ESI-MS).

\section{$P^{2}$-imidazolide 7-methylguanosine 5'-diphosphate, $\operatorname{Im}\left(\mathrm{m}^{7} \mathrm{GDP}\right)$ (compound 14)}

A mixture of triethylammonium salt of 7-methylguanosine $5^{\prime}$ diphosphate $(0.1 \mathrm{~g}, 0.131 \mathrm{mmoles})$, imidazole $(0.178 \mathrm{~g}, 2.63$ 
mmoles), 2,2'-dithiodipyridine (0.230 g, 1.048 mmoles), triethylamine $(18 \mu \mathrm{L})$, and triphenylphosphine $(0.275 \mathrm{~g}, 1.05 \mathrm{mmoles})$ in dimethylformamide $(1.5 \mathrm{~mL})$ was stirred overnight at room temperature. A solution of sodium perchlorate $(0.09 \mathrm{~g}, 0.74 \mathrm{mmoles})$ in anhydrous acetone $(4 \mathrm{~mL})$ was then added. The pure product that appeared as a sodium salt of $\mathrm{P}^{2}$-imidazolide 7-methylguanosine $5^{\prime}$-diphosphate (compound 14) was filtered off, washed with four portions of acetone, and dried over $\mathrm{P}_{4} \mathrm{O}_{10}(0.063 \mathrm{~g}, 0.11$ mmoles, $84 \%)$.

\section{Cap-4 (m $\left.\mathrm{mpppm}_{3}{ }^{6,6,2^{\prime}} \mathrm{Apm}^{2^{\prime}} \mathrm{Apm}^{2^{\prime}} \mathrm{C} \mathrm{pm}_{2}{ }^{3,2^{\prime}} \mathrm{U}\right)$ (compound 15)}

A mixture of the ammonium salt of $\mathrm{pm}_{3}{ }^{6,6,2^{\prime}} \mathrm{Apm}^{2^{\prime}} \mathrm{Apm}^{2^{\prime}}$ $\mathrm{Cpm}_{2}{ }^{3,2^{\prime}} \mathrm{U}$ (compound 13; $10 \mathrm{mg}, 6.8 \mu$ moles), the sodium salt of $\mathrm{P}^{2}$-imidazolide 7-methylguanosine $5^{\prime}$-diphosphate $\operatorname{Im}\left(\mathrm{m}^{7} \mathrm{GDP}\right)$ (compound 14; $18 \mathrm{mg}, 34.3 \mu$ moles) and $\mathrm{ZnCl}_{2}$ (46 mg, 340 $\mu$ moles $)$ in dimethylformamide $(0.08 \mathrm{~mL})$ was stirred for $16 \mathrm{~h}$ at room temperature. The progress of the reaction was monitored by HPLC $\left(\mathrm{Rt}_{\text {substrate }}=17.8 \mathrm{~min}, \mathrm{Rt}_{\text {product }}=16.5 \mathrm{~min}\right.$, using a linear $0 \%-100 \%$ gradient of buffer B in buffer A over $20 \mathrm{~min}$ ). The mixture was then diluted with water $(3.5 \mathrm{~mL})$. Preparative HPLC purification (linear 0\%-100\% gradient of buffer B in buffer A over $50 \mathrm{~min}$ ) gave $\mathrm{m}^{7} \mathrm{Gpppm}_{3}{ }^{6,6,2^{\prime}} \mathrm{Apm}^{2^{\prime}} \mathrm{A} \mathrm{pm}^{2^{\prime}} \mathrm{Cpm}_{2}{ }^{3,2^{\prime}} \mathrm{U}$ (compound 15) as ammonium salt (5.14 mg, $2.64 \mu$ moles, 40\%): ${ }^{1} \mathrm{H}$ NMR $\left(\mathrm{D}_{2} \mathrm{O}, \delta \mathrm{ppm}\right): 8.23(1 \mathrm{H}, \mathrm{H} 8 \mathrm{~s}$, adenine $), 8.05\left(1 \mathrm{H}, \mathrm{H} 8 \mathrm{~s}, N^{6}, N^{6}-\right.$ dimethyladenine), $8.04(1 \mathrm{H}, \mathrm{H} 2 \mathrm{~s}$, adenine), $7.67(1 \mathrm{H}, \mathrm{H} 2 \mathrm{~s}$, $N^{6}, N^{6}$-dimethyladenine), $7.82(1 \mathrm{H}, \mathrm{H} 6 \mathrm{~d}$, cytidine) $7.50(1 \mathrm{H}, \mathrm{H} 6$, s, $N^{3}$-methyluracyl), $5.98\left(2 \mathrm{H}\right.$, broad s, $\mathrm{H}^{\prime} N^{6}, N^{6}, \mathrm{O}^{2^{\prime}}$-trimethyladenosine, $\mathrm{H}^{\prime} \mathrm{O}^{2^{\prime}}$-methyladenosine), $5.90\left(1 \mathrm{H}, \mathrm{H}^{\prime} \mathrm{d}, \mathrm{O}^{2^{\prime}}\right.$ methylcytidine), 5.79 (2H, t, H5 cytidine, H5 $\mathrm{N}^{3}$-methyluracyl), $5.62\left(1 \mathrm{H}, \mathrm{H}^{\prime}{ }^{\prime} \mathrm{s}, 7\right.$-methylguanine $), 5.39\left(1 \mathrm{H}, \mathrm{H}^{\prime} \mathrm{d}, \mathrm{N}^{3}, \mathrm{O}^{2^{\prime}}\right.$ dimethyluridine), 4.90-3.80 (25H, H2' $\mathrm{H}^{\prime}$ ', H4', H5' $\left.5^{\prime \prime} \mathrm{m}\right), 3.96$ $\left(3 \mathrm{H}, \mathrm{s} \mathrm{N}^{7} \mathrm{CH}_{3}\right), 3.71,3.58,3.51,3.24\left(15 \mathrm{H} \mathrm{m}, N^{6}, N^{6}\right.$-dimethyladenosine $\mathrm{O}^{2}-\mathrm{CH}_{3}$, adenosine $\mathrm{O}^{2 \prime}-\mathrm{CH}_{3}$, cytosine $\mathrm{O}^{2^{\prime}}-\mathrm{CH}_{3}$, $\mathrm{N}^{3}, \mathrm{O}^{2^{\prime}}$-dimethyluridine $\mathrm{O}^{2^{\prime}}-\mathrm{CH}_{3}$, and $\left.\overline{\mathrm{N}}^{3}-\mathrm{CH}_{3}\right) ; 4.8$ and $\overline{3} .3$ $\left(6 \mathrm{H}\right.$, broad s $\mathrm{N}-\left(\mathrm{CH}_{3}\right)_{2} \mathrm{~N}^{6}, N^{6}$-dimethyladenine; $\mathrm{m} / \mathrm{z} 1825.5$ by ESI-MS).

\section{$\mathrm{N}^{6}, \mathrm{~N}^{6}, \mathrm{O}^{2^{\prime}}$-trimethyladenosine $5^{\prime}$-monophosphate (compound 16)}

A mixture of $N^{6}, N^{6}, O^{2}$-trimethyladenosine (compound 4; 0.058 g, 0.188 mmoles) and trimethyl phosphate $(1.55 \mathrm{~mL})$ was stirred in an ice bath for $3.5 \mathrm{~h}$. Into this mixture phosphorus oxychloride $(0.044 \mathrm{~mL})$ was added and the progress of the reaction was monitored by analytical HPLC $\left(\mathrm{Rt}_{\text {substrate }}=24.3 \mathrm{~min}, \mathrm{Rt}_{\text {product }}=17.3\right.$ min, linear $0 \%-100 \%$ gradient of buffer B in buffer A, over 20 $\min )$. The mixture was diluted with water $(50 \mathrm{~mL})$, neutralized by the addition of $1.4 \mathrm{M}$ solution of triethylammonium bicarbonate (TEAB), and purified by column chromatography (DEAE-Sephadex, A-25, $\mathrm{HCO}_{3}{ }^{-}$form) using a linear gradient of 0-0.7 M TEAB to obtain $N^{6}, N^{6}, O^{2^{\prime}}$-trimethyladenosine $5^{\prime}$-monophosphate as triethylammonium salt (compound 16;0.067 g, 0.113 mmoles, $60 \%)$.

\section{Cap-1 ( $m^{7} \mathrm{Gpppm}_{3}{ }^{6,6,2^{\prime}}$ A) (compound 17)}

A mixture of triethylammonium salt of $N^{6}, N^{6}, O^{2^{\prime}}$-trimethyladeno-

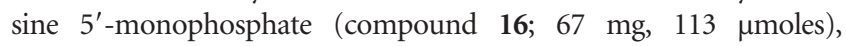

a sodium salt of $\mathrm{P}^{2}$-imidazolide 7-methylguanosine $5^{\prime}$-diphosphate $\operatorname{Im}\left(\mathrm{m}^{7} \mathrm{GDP}\right.$ ) (compound 14; $63 \mathrm{mg}, 109 \mu$ moles), and $\mathrm{ZnCl}_{2}$ (160 mg, $1200 \mu$ moles) in dimethylformamide $(1.2 \mathrm{~mL})$ was stirred for $2 \mathrm{~h}$ at room temperature. The progress of the reaction was monitored by HPLC $\left(\mathrm{Rt}_{\text {substrate }}=17.8 \mathrm{~min}, \mathrm{Rt}_{\text {product }}\right.$ $=14.2 \mathrm{~min}$, linear $0 \%-100 \%$ gradient of buffer $\mathrm{B}$ in buffer $\mathrm{A}$ over $20 \mathrm{~min})$. The mixture was then diluted with water $(60 \mathrm{~mL})$, and EDTA (704 mg, 1.9 moles) was added. Then the solution was neutralized with $\mathrm{NaHCO}_{3}$. The crude product was purified by column chromatography (DEAE-Sephadex, using a linear gradient of $0-1.2 \mathrm{M}$ TEAB) to give (compound 17$)\left(\mathrm{m}^{7} \mathrm{Gpppm}_{3}{ }^{6,6,2^{\prime}} \mathrm{A}\right.$, cap-1) as a triethylammonium salt (15 mg, $13 \mu$ moles, $12 \%):{ }^{1} \mathrm{H}$ NMR $\left(\mathrm{D}_{2} \mathrm{O}, \delta \mathrm{ppm}\right): 8.32\left(1 \mathrm{H}, \mathrm{H} 8 \mathrm{~s}, N^{6}, N^{6}, \mathrm{O}^{2^{\prime}}\right.$-adenine $), 8.09$ $\left(1 \mathrm{H}, \mathrm{H} 2 \mathrm{~s}, N^{6}, N^{6}\right.$-adenine), $6.05\left(1 \mathrm{H}, \mathrm{H}^{\prime}{ }^{\prime} \mathrm{s}, N^{6}, N^{6}, O^{2^{\prime}}\right.$-trimethyladenosine), $5.74\left(1 \mathrm{H}, \mathrm{H} 1^{\prime}\right.$ s, 7 -methylguanosine), $4.63\left(1 \mathrm{H}, \mathrm{H} 2^{\prime}\right.$ $\mathrm{t}, N^{6}, N^{6}, \mathrm{O}^{2}{ }^{\prime}$-trimethyladenosine $), 4.34\left(10 \mathrm{H}\right.$ broad $\mathrm{m}, \mathrm{H} 2^{\prime}$ 7-methylguanosine, H3', H4', H5', H5" 7-methylguanosine and $N^{6}, N^{6}, O^{2^{\prime}}$-trimethyladenosine), $3.97\left(3 \mathrm{H} \mathrm{s}, \mathrm{N}^{7}-\mathrm{CH}_{3}\right) 3.42(9 \mathrm{H}$ broad s, $N^{6}, N^{6}, O^{2}$-trimethyladenosine $\mathrm{O}-\mathrm{CH}_{3}$ and $\left.\mathrm{N}^{6}-\mathrm{CH}_{3}\right)$.

\section{Cloning and expression of the Leishmania elF4E-1 in bacteria for protein purification}

The eIF4E-1 isoform from Leishmania major was amplified by PCR, using genomic DNA as template. The forward primer corresponded to positions 1-21 GGAATTCCATATGTCAGCCCC GTCTTCAGTT- $3^{\prime}$ and the reverse primer corresponded to positions 625-645 5'-CGCGGATCCCTAAGACGCCTCGCCGTGC TT-3'. All primers contained anchor sequences that incorporated the NdeI and BamHI restriction sites at the amino (fwd primer) and carboxy (rev primer) termini, respectively (the restriction sites are underlined). The amplified fragments were digested with NdeI and BamHI and further cloned into the corresponding site of the pHis-parallel vector (Sheffield et al. 1999), resulting in plasmid pLeishIF4E-1. This cloning strategy eliminated the His-tag and generated a recombinant protein that initiated from its own first methionine. The nucleotide sequences of the amplified fragments were compared to the genomic sequence obtained from the L. major genome project.

The recombinant pLeishIF4E-1 was introduced into Escherichia coli BL21 cells and expression was induced at $20^{\circ} \mathrm{C}$ in cultures grown to $\mathrm{OD}_{660} 0.5$ for $3 \mathrm{~h}$, by the addition of $0.5 \mathrm{mM}$ isopropyl1 -thio- $\beta$-D-galactopyranoside (IPTG). Cells were washed once in sonication buffer $(20 \mathrm{mM}$ HEPES at $\mathrm{pH} 7.6,1 \mathrm{mM}$ DTT and 2 mM EDTA, 5\% glycerol), harvested, and disrupted by sonication during $2 \mathrm{~min}$ on ice, using pulses of $20 \mathrm{sec}$ interspaced by intervals of $20 \mathrm{sec}$. The cell extract was clarified by centrifugation during 30 $\mathrm{min}$ at $20,000 \mathrm{~g}$ and the supernatant was loaded on $\mathrm{m}^{7} \mathrm{GTP}-\mathrm{Sepha-}$ rose, equilibrated in the sonication buffer. The protein was eluted in the presence of $150 \mu \mathrm{M}$ of the free cap analog $\mathrm{m}^{7} \mathrm{GTP}$ (Sigma). Alternatively, for fluorescence assays the protein was eluted by high salt $(200 \mathrm{mM} \mathrm{NaCl})$.

\section{Fluorescence measurements and data analysis}

Freshly prepared protein samples were used for the fluorescence assays, after removal of the high salt by filter centrifugation over 4 mL Biomax 5K NMWL columns (Millipore). Protein concentra- 
tions were determined by spectrophotometry, assuming $\varepsilon_{280}=$ $47,500 \mathrm{M}^{-1} \mathrm{~cm}^{-1}$, which were calculated from the amino acid composition (Gill and von Hippel 1989). Fluorescence measurements were performed on a LS-50B Spectrofluorometer (Perkin Elmer Co.), in a quartz semi-micro cuvette (Hellma) with optical lengths $4 \mathrm{~mm}$ and $10 \mathrm{~mm}$ for absorption and emission, respectively. Fluorescence time-synchronized titrations (TST; Niedzwiecka et al. 2002) were performed in $50 \mathrm{mM}$ HEPES/NaOH $(\mathrm{pH}$ 7.2), 100 $\mathrm{mM} \mathrm{NaCl}, 1 \mathrm{mM}$ EDTA, and $1 \mathrm{mM}$ DTT at $20^{\circ} \mathrm{C}$ by adding $1-\mu \mathrm{L}$ aliquots of the cap analog solution to $1.4 \mathrm{~mL}$ of 0.1 or $0.3 \mu \mathrm{M}$ protein solution of LeishIF4E-1. Each titration consisted of 40-65 data points. Fluorescence intensities (excited at 280 or $295 \mathrm{~nm}$ and observed at 337 or $345 \mathrm{~nm}$ ) were corrected for sample dilution $(<5 \%)$ and for the inner filter effect, using empirical calibration curve (Lakowicz 1999). The theoretical curve for the fluorescence intensity $(\mathrm{F})$ as a function of $[\mathrm{L}]$ was fitted to the experimental data points according to the following equation:

$$
\mathrm{F}=\mathrm{F}(0)-[\mathrm{cx}] \cdot\left(\Delta \phi+\phi_{\text {lig-free }}\right)+[\mathrm{L}] \cdot \phi_{\text {lig-free }},
$$

where the equilibrium concentration of the cap-LeishIF4E complex $[\mathrm{cx}]$ is given by

$$
[\mathrm{cx}]=\frac{[\mathrm{L}]+\left[\mathrm{P}_{\mathrm{act}}\right]}{2}+\frac{1-\sqrt{\left(\mathrm{K}_{\mathrm{as}}\left([\mathrm{L}]-\left[\mathrm{P}_{\mathrm{act}}\right]\right)+1\right)^{2}+4 \mathrm{~K}_{\mathrm{as}} \cdot\left[\mathrm{P}_{\mathrm{act}}\right]}}{2 \mathrm{~K}_{\mathrm{as}}} \text {. }
$$

The parameters to be extracted from the fit were as follows: $\mathrm{K}_{\mathrm{as}}$, the association constant; $\left[\mathrm{P}_{\mathrm{act}}\right]$, the concentration of the active protein; $\Delta \phi=\phi_{\mathrm{P}-\text { act-free }}-\phi_{\mathrm{cx}}$, the difference between the fluorescence efficiencies of the apo-protein and the complex; $\phi_{\text {lig-free, }}$ the fluorescence efficiency of the free cap analog in the solution; $\mathrm{F}(0)$, the initial fluorescence intensity (Niedzwiecka et al. 2002). The final $\mathrm{K}_{\mathrm{as}}$ was calculated as a weighted average of two to five independent titrations; numerical least-squares nonlinear regression analysis was performed using ORIGIN 6.0 (Microcal Software Inc.).

\section{ACKNOWLEDGMENTS}

We are indebted to Dr. Nahum Sonenberg from McGill University, Canada, for his generous gift of the eIF4E(28-217) plasmid. This research was supported by the State Committee for Scientific Research (Grants PBZ-KBN 059/T09/10, PBZ-KBN 059/T09/14, and KBN 3 P04A 02125 to E.D., R.K., and R.S., accordingly), and grants from the German-Israel Foundation (GIF, 728-23.2/2002) and Israel Ministry of Health 5440 (to M.S.).

The publication costs of this article were defrayed in part by payment of page charges. This article must therefore be hereby marked "advertisement" in accordance with 18 USC section 1734 solely to indicate this fact.

Received April 5, 2004; accepted May 28, 2004.

\section{REFERENCES}

Bangs, J.D., Crain, P.F., Hashizume, T., McClosky, J.A., and Boothroyd, J.C. 1992. Mass spectrometry of mRNA cap 4 from Trypanosomatids reveals two novel nucleosides. J. Biol. Chem. 267: 9805-9815.

Beaucage, S.L. and Caruthers, M.H. 1981. Deoxynucleotide phosphoramidites-A new class of key iintermediates for deoxypolynucleotide synthesis. Tetrahedron Lett. 22: 1859-1862.

Blachut-Okrasinska, E., Bojarska, E., Niedzwiecka, A., Chlebicka, L.,
Darzynkiewicz, E., Stolarski, R., Stepinski, J., and Antosiewicz, J.M. 2000. Stopped-flow and Brownian dynamics studies of electrostatic effects in the kinetics of binding of 7-methyl-GpppG to the protein eIF4E, Eur. Biophys. J. 29: 487-498.

Cai, A., Jankowska-Anyszka, M., Centers, A., Chlebicka, L., Stepinski, J., Stolarski, R., Darzynkiewicz, E., and Rhoads, R.E. 1999. Quantitative assessment of mRNA cap analogues as inhibitors of in vitro translation. Biochemistry 38: 8538-8547.

Carberry, S.E., Rhoads, R.E., and Goss, D.J. 1989. A spectroscopic study of the binding of $\mathrm{m}^{7} \mathrm{GTP}$ and $\mathrm{m}^{7} \mathrm{GpppG}$ to human protein synthesis initiation factor 4E. Biochemistry 28: 8078-8083.

Gill, S.C. and von Hippel, P.H. 1989. Calculation of protein extinction coefficients from amino acid sequence data. Anal. Biochem. 182: 319-326.

Gingras, A.C., Raught, B., and Sonenberg, N. 1999. eIF4 initiation factors: Effectors of mRNA recruitment to ribosomes and regulators of translation. Annu. Rev. Biochem. 68: 913-963.

Guzaev, A., Salo, H., Azhayev, A., and Lonnberg, H. 1995. A new approach for chemical phosphorylation of oligonucleotides at the 5'-terminus. Tetrahedron 51: 9375-9384.

Jemielity, J., Fowler, T., Zuberek, J., Stepinski, J., Lewdorowicz, M., Niedzwiecka, A., Stolarski, R., Darzynkiewicz, E., and Rhoads, R.E. 2003. Novel "anti-reverse" cap analogs with superior translational properties. RNA 9: 1108-1122.

Kierzek, R., Caruthers, M.H., Longfellow, C.E., Swinton, D., Turner, D.H., and Freier, S.M. 1986. Polymer-supported RNA synthesis and its application to test the nearest-neighbor model for duplex stability. Biochemistry 25: 7840-7846.

Lakowicz, J.R. 1999. Instrumentation for fluorescence spectroscopy. In Principles of fluorescence spectroscopy, 2nd ed. pp. 25-61. Kluwer Academic/Plenum, New York.

Mair, G., Ullu, E., and Tschudi, C. 2000. Cotranscriptional Cap 4 formation on the Trypanosoma brucei Spliced Leader RNA. J. Biol. Chem. 275: 28994-28999.

Mandelboim, M., Barth, S., Biton, M., Liang, X.H., and Michaeli, S. 2003. Silencing of Sm proteins in Trypanosoma brucei by RNA interference captured a novel cytoplasmic intermediate in spliced leader RNA biogenesis. J. Biol. Chem. 278: 51469-51478.

Marcotrigiano, J., Gingras, A.C., Sonenberg, N., Burley, S.K. 1997. Cocrystal structure of the messenger RNA $5^{\prime}$ cap-binding protein (eIF4E) bound to 7-methyl-GDP. Cell 89: 951-961.

Matsuo H., Li, H., McGuire, A.M., Fletcher, C.M., Gingras, A.C., Sonenberg, N., Wagner, G. Structure of translation factor eIF4E bound to $\mathrm{m}^{7} \mathrm{GDP}$ and interaction with $4 \mathrm{E}-$ binding protein. Nat. Struct. Biol. 4: 717-724.

Miyoshi, H., Dwyer, D.S., Keiper, B.D., Jankowska-Anyszka, M., Darzynkiewicz, E., and Rhoads, R.E. 2002. Discrimination between mono- and trimethylated cap structures by two isoforms of Caenorhabditis elegans eIF4E. EMBO J. 21: 4680-4690.

Morris, M.J., MacCoss, M., Naik, S.R., and Ramani, G. 1976. Nucleic acid related compounds. 21. Direct fluorination of uracil and citizen bases and nucleosides using trifluoromethyl hypofluorite. Mechanism, stereochemistry, and synthetic applications. J. Am. Chem. Soc. 98: 7381-7390.

Niedzwiecka, A., Marcotrigiano, J., Stepinski, J., Jankowska-Anyszka, M., Wyslouch-Cieszynska, A., Dadlez, M., Gingras, A.-C., Mak, P., Darzynkiewicz, E., Sonenberg, N., et al. 2002. Biophysical studies of eIF4E cap-binding protein: Recognition of mRNA 5' cap structure and synthetic fragments of eIF4G and 4E-BP proteins. J. Mol. Biol. 319: 615-635.

Robins, M.J., Naik, S.R., and Lee, A.S.K. 1974. Nucleic acid related compounds. 12. The facile and high-yield stannous chloride catalyzed monomethylation of the cis-glycol system of nucleosides by diazomethan. J. Org. Chem. 39: 1891-1899.

Sawai, H., Wakai, H., and Nakamura-Ozaki, A. 1999. Synthesis and reaction of nucleoside $5^{\prime}$-diphosphate imidazolide. A nonenzymatic capping agent for $5^{\prime}$-monophosphorylated oligoribonucleotides in aqueous solution. J. Org. Chem. 64: 5836-5840.

Scaringe, S.A., Francklyn, C., and Usman, N. 1990. Chemical synthesis 


\section{Lewdorowicz et al.}

of biologically active oligoribonucleotides using $\beta$-cyanoethyl protected ribonucleoside phosphoramidite. Nucleic Acid Res. 18: 5433-5441.

Sheffield, P., Garrard, S., and Derewenda, Z. 1999. Overcoming expression and purification problems of RhoGDI using a family of "parallel expression vectors." Protein Expr. Purif. 15: 34-39.

Sproat, B.S. and Lamond, A.I. 1991. 2'-Methyloligoribonucleotides: Synthesis and applications. In Oligonucleotides and Analogues (ed. F. Eckstein), pp. 49-86. Oxford University Press, New York.

Stepinski, J., Waddell, C., Stolarski, R., Darzynkiewicz, E., and Rhoads, R.E. 2001. Synthesis and properties of mRNAs containing the novel "anti-reverse" cap analogues 7-methyl(3'-O-methyl)GpppG and 7-methyl (3'-deoxy)GpppG. RNA 7: 1486-1495.

Szer, W. and Shugar, D. 1968. 2',3'-O-Isopropylidene-3-methyluridine. In Synthetic procedures in nucleic acid chemistry, Vol. 1 (eds. W.W. Zorbach and R.S. Tipson), pp. 433-435. Wiley, New York.

Tomoo, K., Shen, X., Okabe, K., Nozoe, Y., Fukuhara, S., Morino, S., Sasaki, M., Taniguchi, T., Miyagawa, H., Kitamura, K., et al. 2003. Structural features of human initiation factor $4 \mathrm{E}$, studied by X-ray crystal analyses and molecular dynamics simulations. J. Mol. Biol. 328: $365-383$.

Ullu, E. and Tschudi, C. 1995. Accurate modification of the trypanosome spliced leader cap structure in a homologous cell-free system. J. Biol. Chem. 270: 20365-20369.

Varani, G. 1997. A cap for all occasions. Structure 5: 855-858.
Yoshikawa, M., Kato, T., and Takenishi, T. 1967. A novel method for phosphorylation of nucleosides to $5^{\prime}$-nucleotides. Tetrahedron Lett. 50: 5065.

Zeiner, G.M., Sturm, N.R., and Campbell, D.A. 2003. Exportin 1 mediates nuclear export of the Kinetoplastid Spliced Leader RNA. Eukaryot. Cell 2: 222-230.

Zemlicka, J. and Sorm, F. 1965. The reaction of dimethylchloromethyleneammoniumchloride with $2^{\prime}, 3^{\prime}, 5^{\prime}$-tri-O-acetylinosine. A new synthesis of 6-chloro-9-( $\beta$-D-ribofuranosil)purine. Collection Czech. Chem. Commun. 30: 1880-1889.

Zilka, A., Garlapati, S., Dahan, E., Yavelski, V., and Shapira, M. 2001. Developmental regulation of HSP83 in Leishmania: $3^{\prime}$ processing and mRNA stability control transcript abundance and translation is directed by a determinant in the $3^{\prime}$ untranslated region. J. Biol. Chem. 276: 47922-47929.

Zuberek, J., Stepinski, J., Niedzwiecka, A., Stolarski, R., Salo, H., Lonnberg, H., and Darzynkiewicz, E. 2002. Synthesis of tetraribonucleotide cap analogue $\mathrm{m}^{7} \mathrm{GpppA}^{\mathrm{m} 2^{\prime}} \mathrm{pU}^{\mathrm{m} 2^{\prime}} \mathrm{pA}^{\mathrm{m} 2^{\prime}}$ and its interaction with eukaryotic initiation factor eIF4E. Collection Symposium Series. 5: 399-403.

Zuberek, J., Wyslouch-Cieszynska, A., Niedzwiecka, A., Dadlez, M., Stepinski, J., Augustyniak, W., Gingras, A.-C., Zhang, Z., Burley, S.K., Sonenberg, N., et al. 2003. Phosphorylation of eIF4E attenuates its interaction with mRNA $5^{\prime}$ cap analogs by electrostatic repulsion: Intein-mediated protein ligation strategy to obtain phosphorylated protein. RNA 9: 52-61. 

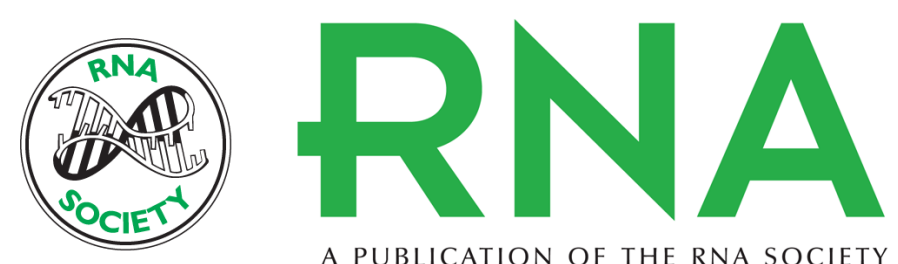

A PUBLICATION OF THE RNA SOCIETY

\section{Chemical synthesis and binding activity of the trypanosomatid cap-4 structure}

MAGDALENA LEWDOROWICZ, YAEL YOFFE, JOANNA ZUBEREK, et al.

RNA 2004 10: 1469-1478

References This article cites 30 articles, 10 of which can be accessed free at:

http://rnajournal.cshlp.org/content/10/9/1469.full.html\#ref-list-1

\section{License}

Email Alerting Receive free email alerts when new articles cite this article - sign up in the box at the Service top right corner of the article or click here.

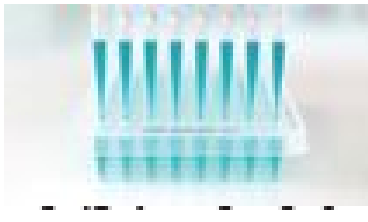

Providing Precise Solutions for your research.

To subscribe to RNA go to:

http://rnajournal.cshlp.org/subscriptions 